\title{
MODERN ECONOMIC AND GEOGRAPHICAL CHARACTERISTICS AND PROSPECTS OF DEVELOPMENT OF ENVIRONMENTAL PROTECTION INFRASTRUCTURE IN THE BAIKAL REGION OF RUSSIA
}

\author{
TATIANA ZABORTSEVA \\ Russian Academy of Sciences, Siberian Branch, V.B. Sochava Institute of Geography, Irkutsk, Russia
}

Manuscript received February 15, 2011

Revised version June 8, 2011

\begin{abstract}
ZABORTSEVA T. Modern economic and geographical characteristics and prospects of development of environmental protection infrastructure in the Baikal region of Russia. Quaestiones Geographicae 30(2), Bogucki Wydawnictwo Naukowe, Poznań 2011, pp. 81-86, 2 figs, 3 tables. DOI 10.2478/v10117-011-0020-2, ISBN 978-83-62662-62-3, ISSN 0137-477X.

AвSTRACT: In the administrative division of Russia, the Baikal region is traditionally considered as embracing three parts: the Irkutsk oblast', the Republic of Buryatia, and Zabaikalsky Kray. Its area is three times larger than that of France $\left(1.6\right.$ million $\left.\mathrm{km}^{2}\right)$, but its population size and density are typical of "the Siberian depth of the country" (4.6 million people, under 3 persons $/ \mathrm{km}^{2}$ ). One of the most important global features of a part of this region - the Baikal Natural Territory - is to ensure the preservation of Lake Baikal as a World Heritage Site. A strategy of environmentally oriented land use determines an adequate level of development of ecological infrastructure and its most important sector - environmental protection infrastructure (EPI). The article presents an analysis of the current infrastructure for managing solid waste, and proposes a forecast scenario of its development with the use of the gravity model in the EPI sector involving recycling collection points.
\end{abstract}

KEY WORDS: territorial organisation, environmental protection infrastructure, gravity model, Baikal region

Tatiana Zabortseva, V.B. Sochava Institute of Geography, Russian Academy of Sciences, Siberian Branch, ul. UlanBatorskaya 1, 664033, Irkutsk, Russia; e-mail: zabti@irigs.irk.ru

\section{Introduction: the notion and role of environmental protection infrastructure and geographical characteristics of the Baikal region}

Environmental protection infrastructure (EPI) is a functionally separate unit of facilities, industries and enterprises for recycling, depositing and neutralising waste - a waste management system which includes the whole complex of meas- ures ensuring control and management of waste streams and information support on the technology of their treatment and recycling (or disposal). The structure and methodological tools for an analysis and assessment of the level of development of a dedicated group of EPI objects and geographical contours are still in development.

The basic function of EPI is to minimise the influence of the disposed-of solid manufacturing and consumer waste on the environment through its selective collection for maximum re- 
covery of recyclables - secondary raw materials. The main factors contributing to the implementation of those functions are, first, an economic one - support and framework management initiated by federal policy, and secondly - functional institutional support (social, economic, regulatory, legislative, etc.). The annual profit lost only due to the lack of systematic selective collection in Russia and the almost complete removal of waste from economic circulation was estimated at up to $\$ 500$ million in the late 1990s (Commentary ... 1999).

The problem of manufacturing and consumer waste management in the Baikal region is among the most important ones in the modern period of market relations, when transformational processes in all spheres of life are not directed, regrettably, toward improving environmental wellbeing. The main object in this region is a World Heritage Site - Lake Baikal. The region embraces three historical members of the federation - the Irkutsk oblast', the Republic of Buryatia, and Zabaikalsky Kray. In the national pattern of socioeconomic types of regions (Atlas ... 2009), the area under consideration is classed as the intermediate type: "poorly developed and in a transition zone" (between leading regions and regions-outsiders) and characterised by generally low economic parameters (Table 1). The region, with a total area of 1,558.1 million $\mathrm{km}^{2}$ and a population of 4,586,500, has a low population density (under 3 people/ $\mathrm{km}^{2}$ ).

The region acts as a support base for the development of the Far Eastern and northern territories of Russia, specialising in power generation, non-ferrous metals, and forest products industry. One of the key features of the region in the terri- torial division of labour caused by its intermediate geographical location in northern Eurasia is transport and communication: the Trans-Siberian and Baikal-Amur intercontinental transport routes with direct access to China and Mongolia pass through the territory, as well as international and domestic airlines, fibre-optic, and other modern communications.

Modern features of the economic complex of the Baikal region and the prospects of its development are predetermined by the location of Lake Baikal as the core of the region - its catchment area has a special environmental management regime. The inclusion of Lake Baikal in the World Heritage List is the main factor determining environmental requirements for the individual localities of this region. The general vector of the 21st-century development of basic sectors here is an expansion of raw materials processing on the basis of the existing and intended agro-industrial economic complex.

A significant part of the Baikal region that ensures the safety of Lake Baikal as a World Heritage Site is the Baikal Natural Territory (BNT), which is divided into three zones by the degree of influence on the lake ecosystem: the central zone, the buffer zone, and the zone of atmospheric effects (Ecological zoning ... 2002; Ecologically oriented ... 2002). The central ecological zone ( 88.5 thous. $\mathrm{km}^{2}-23 \%$ ) has the same boundaries as the World Natural Heritage Site (Fig. 1). The ecological buffer zone (219.6 thous. $\mathrm{km}^{2}-57 \%$ ) includes the remainder of the catchment area of the lake outside the central zone, while the zone of atmospheric influence (78.1 thous. $\mathrm{km}^{2}-20 \%$ ) includes areas adjacent to Lake Baikal within the Irkutsk oblast' where large industry has a negative im-

Table 1. Share of the Baikal region members in the main national economic indicators (2007, in \%).

\begin{tabular}{|c|c|c|c|}
\hline Economic indicators & $\begin{array}{l}\text { Irkutsk } \\
\text { oblast }^{*}\end{array}$ & $\begin{array}{c}\text { Republic } \\
\text { of Burya- } \\
\text { tia }\end{array}$ & $\begin{array}{c}\text { Za- } \\
\text { baikalsky } \\
\text { Kray* }^{*}\end{array}$ \\
\hline GRP & 1.5 & 0.4 & 0.4 \\
\hline Volume of products: extractive industries & 0.7 & 0.1 & 0.3 \\
\hline Volume of products: manufacturing industries & 1.5 & 0.2 & 0.1 \\
\hline Volume of products: production and distribution of electricity, gas and water & 2.0 & 0.5 & 0.5 \\
\hline Agricultural output & 1.8 & 0.6 & 0.6 \\
\hline Turnover of retail trade & 1.4 & 0.5 & 0.5 \\
\hline Investment in fixed assets & 1.8 & 0.3 & 0.6 \\
\hline
\end{tabular}

*Note: the Irkutsk oblast' including the Ust-Orda Buryat Autonomous District, and Zabaikalsky Kray including Chita oblast' and the Agin Buryat Autonomous District (Regions of Russia 2008). 


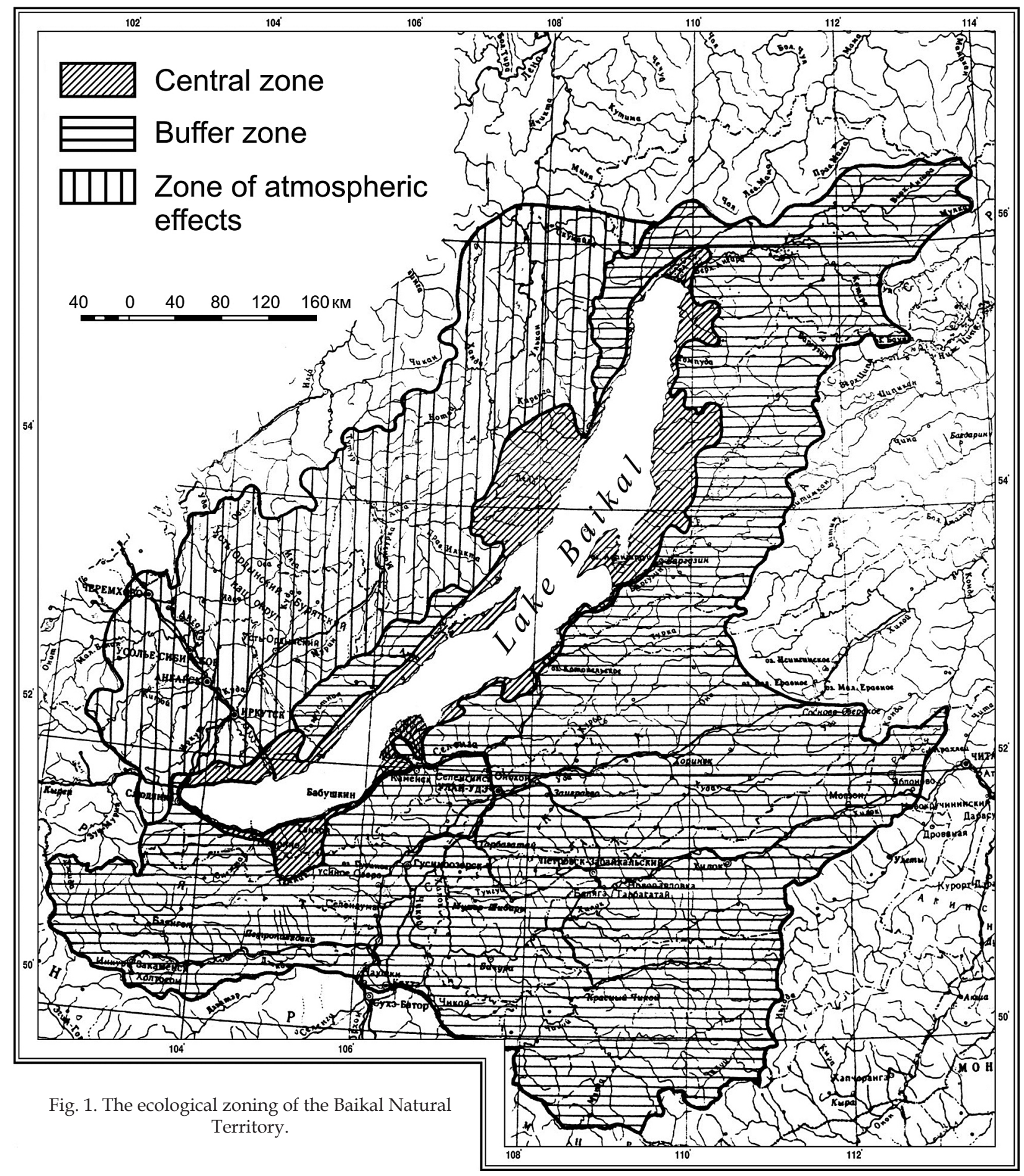

pact on the atmospheric environment of the lake due to the prevailing north-westerly air-masses. The regime of Lake Baikal protection is determined by federal law, which is different from the legal regime set for water bodies in the Russian Federation. Thus, the law provides for a conversion and removal of environmentally hazardous industrial facilities and sets higher requirements for economic activities with a negative impact on the lake ecosystem on the BNT territory.

The work on the ecological zoning of the BNT had a multiplier effect of different socio-economic nature, viz. increased research as well as planning-surveying and managerial-engineering activities in the field of waste management. The geographical features of EPI at the present stage 
of study in terms of territorial organisation are presented in Fig. 2. Let us consider the geographical contours of its functioning and development in two main aspects: EPI for the storage of nonrecyclable solid waste and EPI for the processing of recyclable production waste.

\section{Environmental protection infrastructure in the Baikal region}

\subsection{Waste storage sector}

By area of responsibility, in the Baikal region there operate (or have operated) EPI facilities of the following status:

- federal: waste from other Russian regions, e.g. PA Radon deposits special waste from the neighbouring units: Zabaikalsky Kray and the Republics of Buryatia and Sakha (Yakutia);

- regional: facilities that usually cover a large part of the territory of the federal entity, as exemplified by enterprises for the collection and part processing of metallic and non-metallic recyclables; classical facilities are also the Cheremkhovsky Cardboard-Rubber Plant, the Selenginsky Factory complex, and the Alarsky Waste Plant;

- 'raion' (above-local) level, including EPI facilities of large enterprises, and

- local, serving a specific manufacturing unit or a settlement.

It should be underlined that there is no major highest-ranking EPI facility, like a landfill for toxic industrial waste in the region. Only one modern ecological object of this class has been built in Russia, located in Tomsk, which receives a wide range of toxic industrial wastes (I-IV danger classes) and carries out their processing and disposal (the Russian government granted it a pilot status because of its uniqueness in terms of environmental safety and its processing and disposal technology; Razumov et al. 2005).

The EPI sector of waste storage is characterised by a wide variety of engineering and technical facilities: from the simplest collection points accepting and segregating recyclables to specialised plants (one operating in Ulan-Ude, another planned in Irkutsk), and from storage sites for non-recyclable production waste to complex en-

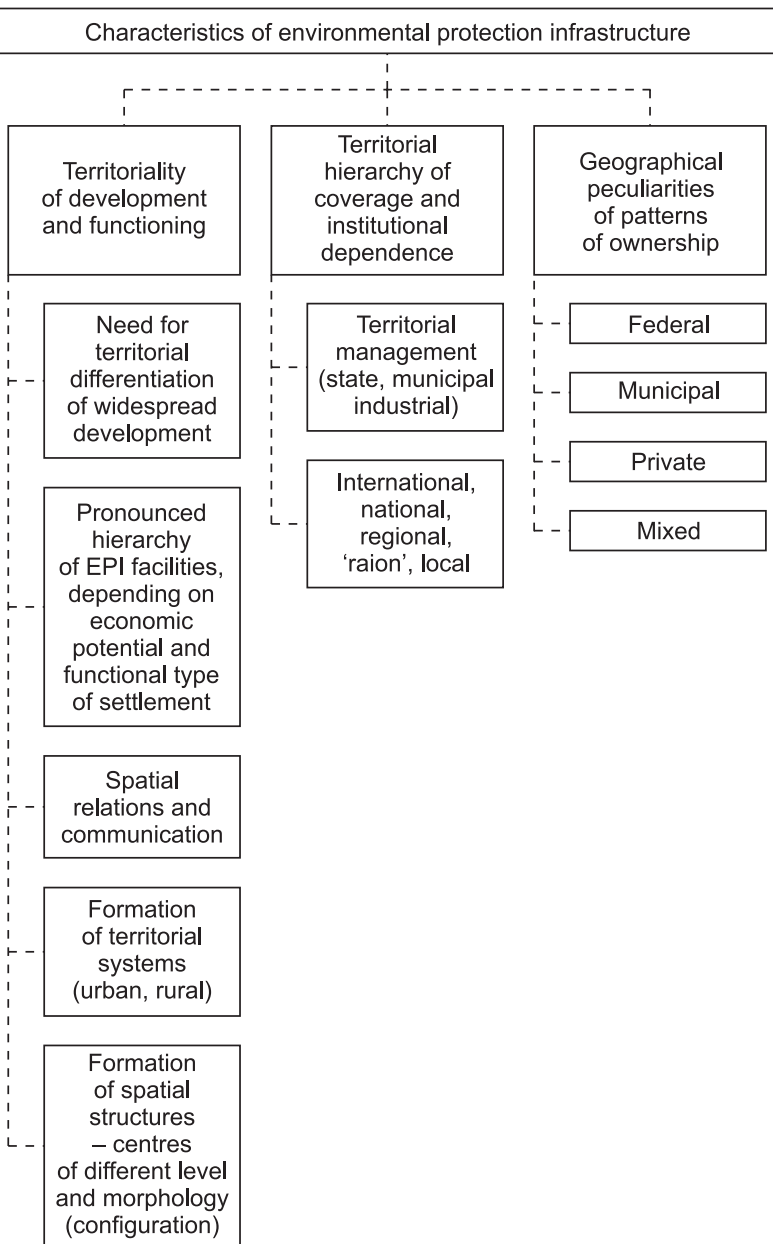

Fig. 2. Characteristics of environmental protection infrastructure.

gineering structures like artificial containers for burying and surface storage of industrial waste (cells, sludge dumps, tailings dams, etc.).

The geographical features of the productive sector of waste management have been presented on a series of maps (Zabortseva et al. 2009; Zabortseva \& Gales 2010) which give the characteristics of environmental protection infrastructure, including facilities for the storage of production and consumer waste, namely aerial dimensions and specific indicators of accumulation (volume per unit area per capita). All the settlements were divided into six groups according to two indicators: (1) the volume of the manufacturing and consumer waste deposited, and (2) the area of burial and surface storage sites. The quantitative criteria for the first indicator are as follows (thous. tonnes): 10, 10.1-100.0, 100.1-500.0, 500.1$2,500.0,2500.1-10,000$, and over 10,000; the criteria of the area occupied by the EPI facilities (ha): 
Table 2. EPI storage and disposal facilities for consumer waste in the Baikal region (2007, in \%).

\begin{tabular}{|l|c|r|c|r|}
\hline \multirow{2}{*}{$\begin{array}{c}\text { Members of the } \\
\text { Baikal region }\end{array}$} & \multicolumn{4}{|c|}{ EPI facilities } \\
\cline { 2 - 5 } & \multicolumn{2}{|c|}{ authorised } & \multicolumn{1}{c|}{ unauthorised } \\
\cline { 2 - 5 } & number & area & number & area \\
\hline Irkutsk oblast' & 18.5 & 28.5 & 32.4 & 45.8 \\
\hline Republic of Buryatia & 35.2 & 37.5 & 47.6 & 25.1 \\
\hline Zabaikalsky Kray & 46.3 & 34.0 & 20.0 & 29.1 \\
\hline Total & 100.0 & 100.0 & 100.0 & 100.0 \\
\hline
\end{tabular}

10, 10.1-50.0, 50.1-100.0, 100.1-250, 250.1-500.0, and over 500 .

Among the member units of the Baikal region, the largest number of EPI objects of the production waste profile is concentrated in the Irkutsk oblast': ash dumps, sludge ponds, tailings dams, etc. The second and third positions belong to Zabaikalsky Kray and the Republic of Buryatia, respectively. Currently more than 2,700 facilities for the storage and disposal of consumer (household and equivalent) waste are officially registered in the Baikal region. Regional branches of Rostekhnadzor (the Russian Technical Supervisory Authority) register them as approved (authorised) landfills (in the constitutive package of documents there is at least a land-use permission) and illegal (unauthorised) dumps (actually acting as storage sites, but legally flawed, without a land-use permission). General characteristics of the subjects are presented in Table 2 .

The chief qualitative and quantitative indicators of this block of EPI are as follows: there are two unauthorised objects for one authorised facility, and the average size of an authorised facility (2.57 hectares) is more than double that of an unauthorised one (1.12 ha). By area occupied by EPI facilities, the Irkutsk oblast' is the leader $(1,628.8 \mathrm{ha})$, followed by the other two regional entities with barely differing indices (the Republic of Buryatia and Zabaikalsky Kray, 1443.1 and 1437.7 ha, respectively).

In the Baikal region there is only one waste processing plant, functioning since 2007 in the town of Ulan-Ude, with a special landfill of 33.2 ha. The capacity of its first waste-sorting station is 80 thousand tonnes per year, and that of the second one, now under construction, is 40 thousand tonnes per year. In the first stage the proportion of recyclables recovered (waste paper, plastic, glass, ferrous and non-ferrous metals) is $10 \%$ of the incoming volume. The project envisages the construction of second-stage industrial facilities for the processing of solid waste, the main one being a refinery with a department of biothermal composting of organic waste, a line for deep processing of recyclables (waste polymers), and a pyrolysis plant for the non-recyclable part of the waste.

In the current market conditions, in the absence of a state contractor, the produced waste is not a subject of competitive relations. There is inefficient use and wrong allocation of funds offered by private business for investment in facilities processing and storing production and consumer waste.

\subsection{Recycling collection sector and its relation to the settlement system}

A comparison of the spatial structure of the pre-reform recycling collection sector and the contemporary one developing in quite different economic conditions leads to the following conclusions. A recyclables collecting network was set up before the 1990s, but then it lost its peripheral local-level collection units (fixed and mobile collection sites) during the economic reform. However, by 2010 it had gradually revived in the old urban as well as transport and communication centres of the Irkutsk oblast'. Official statistics record modern recyclables collecting activity in only 9 out of the 23 towns where this activity was carried out previously. For more than half a century of recycling collection, the geographical pattern of this EPI sector has been relatively stable, and is now probably generally recovering in the new market conditions (and 'reborn' for non-metallic recyclables) if provided with various forms of government support (as shown by the experience of economically developed countries). The inertia of the territorial organisation of recycling collection infrastructure is significant. The geography of EPI should, ideally, reflect the spatial pattern and scale of the economic activity of the region.

The expected pattern of location of the recycling collection facilities based on the rank of settlements was calculated using the gravity model. It can complement the preparatory theoretical ba- 
sis for a future spatial organisation of nature protection in the Irkutsk oblast' (Zabortseva 2005).

The original principle of the location pattern of recyclables-collecting facilities is that of its correspondence with settlement systems. These systems were determined by calculating zones of influence of settlements using the gravity model: influence potential $=$ power $/$ distance .

There is a close correlation between the population number of a settlement and the quantitative and qualitative composition of enterprises and institutions of social infrastructure serving it; this is due to the natural development of the settlement network and the Russian practice of town planning. Since the research concerns consumer recyclables, the indicators of power are standard characteristics of available services used in the management practice in this field.

The model was based on the possibility of population movement throughout the area using all modes of transport. The zones of influence of the centres were calculated on the basis of actual routes and their length. In descending order of importance, the following ways of communication were taken into account: a) surfaced roads, b) unsurfaced roads, d) rail lines, e) navigational routes, and e) air routes.

As a result of calculations, for each locality three most important population service centres were identified. By the magnitude of the integrated indicator, these centres were ranked as follows: 1 - main, 2 - supplementary, and 3 secondary. The full data set included 1,572 settlements of the region for which 67 top-ranking centres were identified, 7 of which are presented in Table 3.

The identified zones of actual influence of settlements of different rank can serve as one of the most important sources of information for regional planning of enterprises and EPI facili-

Table 3. Potential and rank of the settlement system centres in the Irkutsk oblast' of the Baikal region.

\begin{tabular}{|c|c|r|c|}
\hline № & Settlement & Potential & Rank \\
\hline 1. & Irkutsk & $4,574,238$ & 1 \\
\hline 2. & Angarsk & $1,539,202$ & 1 \\
\hline 3. & Cheremkhovo & 483,963 & 1 \\
\hline 4. & Tulun & 472,538 & 1 \\
\hline 5. & Bratsk & 397,727 & 1 \\
\hline 6. & Usolye-Sibirskoye & 368,467 & 1 \\
\hline 7. & Zima & 295,038 & 1 \\
\hline
\end{tabular}

ties for the recovery and use of recyclables in the Baikal region.

\section{Concluding remarks}

The currently adopted policy of enhancing regional development and strengthening municipal government requires the strengthening of the hierarchical system of local centres, equipping them with market infrastructure, and reinforcing their multifunctional role, also in the recovery sphere. The zones of influence of individual units of the settlement system calculated with the help of the gravity model provide a spatial basis for the planning of EPI location, also in the specific conditions of the Baikal region. The research on the geography of the EPI facilities of the waste storage sector can identify problem areas, which is especially important in the Baikal region where ecologically sustainable development is a key to successful advancement of tourism at a world level.

\section{References}

Atlas of the socio-economic development of Russia, 2009. Cartographic Production Association "Kartographia".

Commentary to the Federal Law "On Production and Consumer waste", 1999. State Committee of RF for Environmental Protection, Moscow-Petersburg.

Ecologically oriented land-use planning in the Baikal region. Baikal Natural Territory, 2002. IG SO RAN, Irkutsk.

Ecological zoning of the Baikal Natural Territory, 2002. Irkutsk.

Razumov N.M., Gerasimenko O.M. \& Koreneva G.I., 2005. Experience in design construction and operation of the landfill of toxic industrial waste in Tomsk. 4th International Congress on Waste Management "WasteTech-2005": Proceedings (Moscow, May 31 - June 3, 2005), SIBICO International: 252-253.

Regions of Russia. Socio-economic indicators, 2008. Statistics digest, Federal State Statistics Service, Moscow.

ZABORTSEVA T.I., 2005. Regional infrastructure for waste handling. Siberian Branch of Russian Academy of Science, Novosibirsk.

Zabortseva T.I. \& GAlEs D.A., 2010. Mapping of regional environmental protection infrastructure. Thematic mapping to create in spatial data infrastructure. Proceedings of the 9th Scientific Conference on Thematic Cartography (Irkutsk, November 9-12, 2010). IG SB RAS, Irkutsk: 180-182.

Zabortseva T.I., Pomazkova N.V., Handazhapova L.M. \& Bogdanov V.N., 2009. Solid production and consumer waste. Natural resources. Economy and population of the Baikal region (series of CD maps of the Baikal region, 1:7,500,000). 